\title{
Measurement of urinary lipopolysaccharide antibodies by ELISA as a screen for urinary tract infection
}

\author{
A P MacGowan, R J Marshall, P Cowling, D S Reeves
}

\begin{abstract}
Five hundred and twenty two clinical urine specimens submitted for routine microbiological examination were tested in parallel by conventional microscopy and culture and for lipopolysaccharide antibodies by an enzyme linked immunoabsorbent assay (ELISA) to assess the ELISA as a screen for urinary tract infection. When the ELISA alone was compared with routine methods the specificity sensitivity, and predictive value of positive and negative tests was $73 \cdot 2 \%, 75 \cdot 7 \%, 51 \cdot 1 \%$ and $38 \cdot 5 \%$. For ELISA with microscopy the same variables were $71 \cdot 1 \%, 82 \cdot 2 \%$, and $92 \cdot 4 \%$ and 94.7\%, respectively. The ELISA absorbency increased with increasing bacterial numbers, but results varied widely. Only $65 \cdot 4 \%$ of urines which contained $\geq 10^{5}$ bacterial $/ \mathrm{ml}$ were positive by ELISA; $36.8 \%$ of urines with $<10^{3}$ bacteria/ml were positive by ELISA; $100 \%$ of $\geq 10^{5}$ bacteria/ml cultures of Pseudomonas sp $(n=4)$, Staphylococcus aureus $(\mathrm{n}=3)$, and Streptococcus faecalis $(n=2)$ were positive by ELISA but only $71.4 \%$ of Proteus sp $(n=7)$, $61 \cdot 4 \%$ coliforms $(n=70)$, and $25 \%$ of coagulase negative staphylococci $(n=4)$.

It is concluded that further development is required before the ELISA can be used for routine screening for urinary tract infection.
\end{abstract}

Urinary bacteriology is a principal part of the workload of most clinical microbiology departments, hence the efficient and effective use of staff and material is of considerable importance. Many urine specimens submitted for laboratory examination do not have clinically important abnormalities; early and cost effective screening out of these specimens may therefore result in more appropriate use of resources. Dipsticks have been advocated in this role but studies have shown that increased costs and staff time are likely if they are used. ${ }^{2}$

Antibody-coated bacteria have been used for many years to discriminate between upper and lower urinary tract infection, but unbound antibody may also be detected in urine. ${ }^{3}$ High concentrations of unbound urinary IgG and IgA have been detected by enzyme linked immunoabsorbent assay (ELISA) in acute pyelonephritis, but in lower tract infection concentrations were low.
Secretory IgA may, however, be detected in patients with cystitis or asymptomatic bacteriuria. ${ }^{45}$ Hence it has been suggested that the detection of antibodies by the use of a polyspecific lipopolysaccharide antigen in an ELISA may provide a useful screening test for urine before culture or that it could replace microscopy. ${ }^{6}$

We report on the evaluation of a prototype ELISA (Melisa, Utilisa) developed by Walker Diagnostics, Cambridge, England, for the detection of urinary lipopolysaccharide antibody and the evaluation of its role as a screening test for urinary tract infection.

\section{Methods}

Conventional urine microscopy and culture on CLED agar were performed on all specimens. An inverted microscope was used on $60 \mu \mathrm{l}$ of urine in 96-well flat bottomed microtitre trays. Red blood and white cellcounts were expressed per high power field. Culture comprised a $2 \mu$ l standard loop on to a half plate for each specimen. Urine specimens with no growth after 18 hours of incubation were assumed to have $\leq 10^{3}$ bacteria $/ \mathrm{ml}$. In parallel, urine specimens were also tested using the manufacturer's recommendations in a solid phase enzyme linked immunoabsorbent assay (ELISA) for detection of lipopolysaccharide antibodies (Walker Diagnostics Cambridge, Cambridgeshire, England).

Briefly, $200 \mu \mathrm{l}$ of positive and control reagent with a defined absorbency cut-off as well as test urines were pipetted into 96 -well microtitre trays and pins coated with purified lipopolysaccharide were inserted and incubated for 10 minutes at room temperature. The pins were washed and transferred to $100 \mu \mathrm{l}$ of enzyme conjugate in a second plate and incubated for a further 10 minutes. The pins were washed again and placed in $200 \mu \mathrm{l}$ of enzyme substrate (0-phenylenediamine-hydrochloride). The reaction was stopped by the addition of $50 \mu \mathrm{l}$ $4 \mathrm{M}$ sulphuric acid after 10 minutes.

The optical density was read at $492 \mathrm{~nm}$ on a microplate reader. For each assay the samples were compared with the cut off value (COV). Samples with absorbency lower than the COV were negative, and those greater were positive, provided the positive control was more than five times the COV optical density. To enable optical densities to be compared between different ELISA plates a "corrected absorbency" was derived by multiplying the test 
Table 1 Comparison of urine microscopy, culture, and ELISA tests individually and in combination

\begin{tabular}{|c|c|c|c|c|c|}
\hline \multirow[b]{2}{*}{ Source } & \multirow[b]{2}{*}{ Comparisons } & \multirow[b]{2}{*}{ Sensitivity (\%) } & \multirow[b]{2}{*}{ Specificity (\%) } & \multicolumn{2}{|c|}{ Predictive value } \\
\hline & & & & Positive & Negative \\
\hline General practice $(n=246)$ & $\begin{array}{l}E L I S A v M C \\
\text { WCC + ELISA } v \text { MC } \\
\text { RBC + WCC + ELISA } v M C \\
\text { RBC + WCC } v \text { MC }\end{array}$ & $\begin{array}{l}75 \cdot 0 \\
83 \cdot 3 \\
83 \cdot 3 \\
77 \cdot 9\end{array}$ & $\begin{array}{l}78 \cdot 5 \\
77 \cdot 8 \\
74 \cdot 7 \\
90 \cdot 3\end{array}$ & $\begin{array}{l}54 \cdot 1 \\
53 \cdot 1 \\
48 \cdot 8 \\
75 \cdot 0\end{array}$ & $\begin{array}{l}90 \cdot 3 \\
93 \cdot 9 \\
93 \cdot 9 \\
91 \cdot 6\end{array}$ \\
\hline Hospital $(n=275)$ & $\begin{array}{l}\text { ELISAvMC } \\
\text { WCC + ELISA } v \text { MC } \\
\text { RBC + WCC + ELISA } v M C \\
\text { RBC + WCC } v \text { MC }\end{array}$ & $\begin{array}{l}76 \cdot 7 \\
79 \cdot 3 \\
80 \cdot 7 \\
71 \cdot 9\end{array}$ & $\begin{array}{l}69 \cdot 4 \\
67 \cdot 6 \\
68 \cdot 4 \\
87 \cdot 1\end{array}$ & $\begin{array}{l}31 \cdot 3 \\
29 \cdot 5 \\
30 \cdot 3 \\
57 \cdot 5\end{array}$ & $\begin{array}{l}94 \cdot 2 \\
95 \cdot 0 \\
95 \cdot 4 \\
92 \cdot 7\end{array}$ \\
\hline General practice and hospital $(n=521$ ) & $\begin{array}{l}E L I S A v M C \\
\text { WCC + ELISA vMC } \\
\text { RBC + WCC + ELISA } v M C \\
\text { RBC + WCC } v \text { MC }\end{array}$ & $\begin{array}{l}75 \cdot 7 \\
81 \cdot 5 \\
82 \cdot 2 \\
75 \cdot 2\end{array}$ & $\begin{array}{l}73 \cdot 2 \\
71 \cdot 8 \\
71 \cdot 1 \\
88 \cdot 5\end{array}$ & $\begin{array}{l}41 \cdot 1 \\
39 \cdot 4 \\
38 \cdot 5 \\
66 \cdot 2\end{array}$ & $\begin{array}{l}92 \cdot 4 \\
94 \cdot 5 \\
94 \cdot 7 \\
92 \cdot 2\end{array}$ \\
\hline
\end{tabular}

$\mathrm{MC}=$ Conventional microscopy and culture; $\mathrm{WCC}=$ White cell count; $\mathrm{RBC}=$ red blood cell count .

absorbency by a factor derived by dividing the average COV for all plates by the COV for the plate on which the test was read.

A positive urine sample by conventional methods was defined as $\geq 10^{5}$ bacteria $/ \mathrm{ml}$ in a pure or predominant growth in the absence of pyuria ( $<10$ white cells/high power field) or $\geq 10^{4}$ bacterial $/ \mathrm{ml}$ in pure or predominant growth and $>10^{5}$ bacterial $/ \mathrm{ml}$ of two species in the presence of pyuria ( $\geq 10$ white cells/ high power field).

Isolates were identified by conventional means, ${ }^{7}$ and test sensitivities, specificities, and predictive values of negative and positive tests calculated according to Boreland and Stoker. ${ }^{8}$

\section{Results}

Five hundred and twenty two urines were tested. Two hundred and forty seven came from patients attending general practitioners and 275 from inpatients or those attending hospital outpatient clinics. No specimens from antenatal clinics sent for screening for bacteriuria in pregnancy were included. Four hundred and twenty five specimens were midstream specimens, 51 were catheter urines, 21 bag urines, one was an endoscopic urine, and for 24 the site of sampling was unknown.

Table 2 ELISA absorbencies and their relation to semiquantitative bacteria counts

\begin{tabular}{|c|c|c|c|}
\hline \multirow[b]{2}{*}{ Numbers of bacteria } & \multicolumn{2}{|c|}{ Corrected absorbency } & \multirow{2}{*}{$\begin{array}{l}\text { Percentage of } \\
\text { urine specimens } \\
\text { ELISA positive }\end{array}$} \\
\hline & Range & Mean & \\
\hline $\begin{array}{l}\leq 10^{3} \mathrm{cfu} / \mathrm{ml}(\mathrm{n}=219) \\
10^{3}-<10^{4} \mathrm{cfu} / \mathrm{ml}(\mathrm{n}=163) \\
10^{+}-\leq 10^{5} \mathrm{cfu} / \mathrm{ml}(\mathrm{n}=32) \\
>10^{5} \mathrm{cfu} / \mathrm{ml}(\mathrm{n}=107)\end{array}$ & $\begin{array}{l}0.070-1.637 \\
0.069-2.522 \\
0.081-1.955 \\
0.075-2.983\end{array}$ & $\begin{array}{l}0 \cdot 203 \\
0 \cdot 239 \\
0 \cdot 423 \\
0 \cdot 469\end{array}$ & $\begin{array}{l}36 \cdot 8(n=81) \\
35 \cdot 0(n=57) \\
43 \cdot 8(n=14) \\
65 \cdot 4(n=70)\end{array}$ \\
\hline
\end{tabular}

Table 3 ELIS $A$ absorbency in urines with $>10^{5}$ bacteria/ml cultures

\begin{tabular}{|c|c|c|c|}
\hline \multirow[b]{2}{*}{ Species } & \multicolumn{2}{|c|}{ Corrected absorbency } & \multirow{2}{*}{$\begin{array}{l}\text { Percentage detected } \\
\text { by ELISA }\end{array}$} \\
\hline & Range & Mean & \\
\hline $\begin{array}{l}\text { Gram negative isolates: } \\
\text { Coliforms }(\mathrm{n}=70) \\
\text { Proteus } \mathrm{sp}(\mathrm{n}=7) \\
\text { Pseudomonas } \mathrm{sp}(\mathrm{n}=4)\end{array}$ & $\begin{array}{l}0.083-2.983 \\
0.094-1.790 \\
0.191-1.790\end{array}$ & $\begin{array}{l}0.440 \\
0.553 \\
0.853\end{array}$ & $\begin{array}{l}61 \cdot 4 \\
71 \cdot 4 \\
100\end{array}$ \\
\hline $\begin{array}{l}\text { Gram positive isolates: } \\
\text { S aureus }(\mathrm{n}=3) \\
\text { S epidermidis }(\mathrm{n}=3) \\
\text { S saprophyticus }(n=1) \\
\text { S faecalis }(\mathrm{n}=2) \\
\text { Candida } \mathrm{sp}(\mathrm{n}=2)\end{array}$ & $\begin{array}{l}0 \cdot 218-1 \cdot 819 \\
0 \cdot 119-0 \cdot 200 \\
0 \cdot 181-0 \cdot 195 \\
0 \cdot 140-0 \cdot 199\end{array}$ & $\begin{array}{l}0.903 \\
0 \cdot 158 \\
0 \cdot 125 \\
0 \cdot 188 \\
0 \cdot 169\end{array}$ & $\begin{array}{r}100 \\
33 \\
0 \\
100 \\
50\end{array}$ \\
\hline
\end{tabular}

One hundred and six $(20 \cdot 3 \%)$ were positive by conventional methods-60 (24.3\%) from general practice, and $46(16.7 \%)$ from hospital patients. The ELISA by itself and in combination with pyuria or haematuria, or both $(>10$ red blood cells/high power field) was compared with conventional microscopy and culture. For comparison, routine microscopy was also compared with microscopy and culture. Table 1 shows the sensitivities, specificities, and predictive values of these tests for urine samples from hospital and general practice patients.

ELISA and microscopy combined had a negative predictive value of $94.7 \%$ for all urine specimens while the corresponding figures for microscopy or ELISA alone were 92.2 and $92.4 \%$, respectively. The specificity of the ELISA was less than microscopy alone, and the positive predictive value of all the tests was less in hospital than general practice patients.

There was no correlation between white cells/high power fields or red blood cells/high power fields and absorbency $\left(r^{2}=0 \cdot 1153\right.$ and 0.0477 , respectively, but all urine samples with $\geq 100$ red blood cells/high power field were positive by ELISA (data not shown). As: the numbers of bacteria increased then the ELISA absorbency increased (table 2), but there was a large range of values. The percentage of specimens that were ELISA positive increased with increasing bacterial counts from $36.8 \%$ with $\leq 10^{3}$ bacterial $/ \mathrm{ml}$ (no growth on CLED) to $65.4 \%$ with $\geq 10^{5}$ bacterial $/ \mathrm{ml}$.

The sensitivity of the ELISA at detecting antibody in urine samples with $\geq 10^{5}$ bacteria/ $\mathrm{ml}$ of different urinary pathogens is shown on table 3: $61 \cdot 4 \%$ of urines with $\geq 10^{5}$ coliforms $\mathrm{ml}$ were ELISA positive, while all Pseudomonas $\mathrm{sp}$, Staphylococcus aureus, and Streptococcus faecalis were detected. Coagulase negative staphylococci and Candida were detected less frequently.

Table 4 shows the percentage of urine samples positive by conventional methods at different corrected absorbencies. As the absorbency increases the percentage of positive urine samples increased from $5-10 \%$ to about $40 \%$, but even at high optical densities only $39 \%$ of urines were judged positive by conventional culture. If the average $\mathrm{COV}(0 \cdot 179)$ is compared with the range of absorbencies then it lies near the majority of the results; hence small 
Table 4 Percentage of urine samples positive by conventional microscopy and culture at different corrected absorbencies by ELISA

\begin{tabular}{llc}
\hline $\begin{array}{l}\text { Corrected absorbency } \\
\text { by ELIS } A\end{array}$ & $\begin{array}{l}\text { Percentage of } \\
\text { urines positive by } \\
\text { conventional methods }\end{array}$ & $\begin{array}{l}\text { Total number of } \\
\text { urine samples }\end{array}$ \\
\hline $0.041-0.08$ & $8 \cdot 3$ & 12 \\
$0.081-0.12$ & $6 \cdot 2$ & 145 \\
$0.121-0.16$ & 16.7 & 120 \\
$0.161-0.20$ & $25 \cdot 0$ & 72 \\
$0.201-0.24$ & 18.5 & 27 \\
$0.241-0.28$ & 36.4 & 16 \\
$0.281-0.32$ & $18 \cdot 7$ & 19 \\
$0.321-0.36$ & 42.1 & 12 \\
$0.361-0.40$ & 41.7 & 77 \\
\hline 0.40 & 39.0 & \\
\hline
\end{tabular}

Average $\mathrm{COV}=0 \cdot 179$.
Changing the cut off value in the ELISA will change the specificity and sensitivity of the test, but as only $40 \%$ of urine samples with high absorbencies are positive by conventional tests, and $5-10 \%$ of those with low absorbencies, a greater difference in these percentages would be needed to make this worthwhile.

At present the prototype ELISA under test as a screening method for urinary tract infection lacks the technical characteristics which would make it suitable in this role, mainly because of the high number of false positive and negative results when compared with conventional microscopy and culture. This may be because of problems with conventional methods such as the presence of antibiotic or a significant number of bacteria at less than $10^{3}$ $\mathrm{cfu} / \mathrm{ml}$ in the urine, both of which would produce false positive results by ELISA. False negative results may occur because of the inability of the test to detect the full range of antibody classes or specificities produced in response to a urinary tract infection, or by failures of a patient to mount an antibody response-for example, immunocompromised hospital patients. If some of these problems can be overcome studies of workloads and costs could be performed.

We acknowledge the help of Walker Diagnostics, Cambridge, England.

1 Barker B, Ratcliffe JG, Turner GC. Urine screening for leucocytes by dipstick and reflective spectrophotometry. Med Lab Sci 1989;9:97-100.

2 MacGowan AP, Cowling P, Marshall R, Reeves DS Screening of urines with dipstick; does it reduce workload and consumable costs? J Clin Pathol 1990;43:875.

3 Ratner JJ, Thomas VI, Sanford BA, Forland M. Bacteriaspecific antibody in urine of patients with acute pyelonephritis and cystitis. $J$ Infect Dis 1981;143:404-12.

4 Jodal U, Ahlstedt S, Carlsson B, Hanson LA, Lindberg U, Sohl A. Local antibodies in childhood urinary tract Sohl A. Local antibodies in childhood
infection. Int Arch Allergy 1974;47:537-46.

5 Alkerlund AS, Ahlstedt S, Hanson LA, Jodal U. Antibody responses in urine and serum against $\mathrm{E}$ coli 0 antigen in childhood urinary tract infection. Acta Pathol Microbio Scand (C) 1979;87:29-36.

$6 \mathrm{McKenzie} H$, Young DN. Antibody to coliform antigens in samples from patients with symptoms of urinary tract infection. J Clin Pathol 1987;40:787-92.

7 Lewis DA. Bacteriology of urine. In: Hawkey PM, Lewis DA, eds. Medical bacteriology: a practical approach. Oxford: IRL Press, 1989:1-19.

8 Boreland PG, Stoker M. Dipstick analysis for screening of paediatric urine. J Clin Pathol 1986;39:1360-2. 